\title{
Catalogues of historical earthquakes in Italy
}

\author{
Romano Camassi \\ Istituto Nazionale di Geofisica e Vulcanologia, Sezione di Milano, Sede di Bologna, Italy
}

\begin{abstract}
A complete survey of historical earthquake investigation in Italy cannot be compressed into a few pages, since it would entail making a summary of widely different phases of research (performed by past scholars and by contemporary scientists and historians) and taking into account the widely different historical contexts, methodological assumptions and critical awareness of each of them. This short note only purposes to chart the main stages of the progress made by Italian historical seismology, from the late 17th century compilation by Bonito (1691) up to the latest parametric catalogue (Working Group CPTI, 1999).
\end{abstract}

Key words historical seismology - earthquake catalogue

\section{Italian earthquake catalogues up to 1980}

\subsection{From Roman paradoxographers to Bonito's Terra Tremante (1691)}

The tradition of earthquake studies in Italy is very long; its origins go back to a classical literary genre known as «paradoxography» or collection of marvels and curiosities (Pauly and Wissowa, 1949). The earliest listings of Italian earthquakes were compiled by paradoxographers such as Julius Obsequens, a Roman of uncertain date but generally placed about the middle of 4th century A.D., who gave an account of the prodigies and portents that occurred in Rome between 249-12 B.C. The first «modern» Italian earthquake lists were included in treatises written in the aftermath of large (or even less than large) earthquakes, following

Mailing address: Dr. Romano Camassi, Istituto Nazionale di Geofisica e Vulcanologia, Sezione di Milano, Sede di Bologna, Via D. Creti 12, 40128 Bologna, Italy; e-mail: camassi@ bo.ingv.it a vogue set by humanist Giannozzo Manetti in the wake of the catastrophic Southern Italy earthquake of December 1456 (Manetti, 1457). Many such works were written in the 16th and 17th centuries (table I), culminating in the best and largest of them all, Terra Tremante (Bonito, 1691), a worldwide compilation including about one hundred European earthquakes (seventy of them Italian) and some tens of reports of earthquakes from Canada, China, Japan, Panama, Peru and the Philippines. These are based on large selections from original sources, often transcribed complete. The originals of some of these sources were later destroyed, which increases the usefulness of this great compilation.

\subsection{The Age of Enlightement and National States (18th-19th centuries)}

From the 18th century to the first half of the 19th century, earthquake listings go out of fashion. There is no lull in Italian seismicity (far from it, in fact) but - with a few remarkable exceptions such as Mongitore (1743), on Sicilian earthquakes, and Soldani (1798) on Siennese ones - treatise writers seem more interested in debating whether earthquakes are caused by 
Romano Camassi

Table I. Main Italian compilers of earthquake lists in the 16th and 17th centuries.

\begin{tabular}{ccc}
\hline \hline Compiler & Earthquake & Time span \\
\hline Giannozzo Manetti (1457) & 1456 Southern Italy & Antiquity-1456 \\
Colanello Pacca (1563) & 1561 Val D’Agri & Antiquity-1561 \\
Pirro Ligorio (1574-1577) & 1570 Ferrara & Antiquity-1570 \\
Filippo da Secinara (1652) & 1646 L'Aquila & Antiquity-1646 \\
Marcello Bonito (1690) & 1688 Campania & Antiquity-1688 \\
\hline
\end{tabular}

electricity or not, than in piling up macroseismic data. This trend was reversed again in the second half of the 19th century, thanks to the Europeanwide birth of national institutions for the study of meteorological and seismological phenomena (Camassi, 1991; Ferrari, 1992). In Italy, the creation of the earliest observational networks in the 1870 s went hand in hand with the resumption of large scale collection of macroseismic data, first advocated by Alessandro Serpieri, Antonio Malvasia and Michele Stefano De Rossi. In 1874 De Rossi founded the Bullettino del Vulcanismo Italiano, that only three years later could boast of an 85-strong national network of correspondents. The Italian Central Meteorological Office (UCM) was created in 1876, and in 1887 it branched out with a specialised Geodynamic Service, becoming the Central Office for Meteorology and Geodynamics (UCMG).

By 1890 the Geodynamic Service network numbered more than 900 stations and observatories, whose output (macroseismic questionnaires and reports) featured regularly (under the heading News of earthquakes observed in Italy) in the Bulletin published from 1895 to 1913 by the Italian Seismological Society (founded in 1895).

\subsection{Rounding up past knowledge: Baratta's I Terremoti d'Italia (1901)}

In the second half of the 19th century, along with the development of State-sponsored earthquake-monitoring, the ancient tradition of earthquake listing flourished anew in Italy (fig. 1) as in the rest of Europe, thanks to the groundbreaking efforts of people such as Hoff (1840-1841),
Perrey (1848), Mallet (1853, 1854, 1855), Volger (1857), Schmidt (1879), Mercalli (1883), Kispatich (1891-1892), Baratta (1901) and many others.

The huge compilation I terremoti d'Italia (Baratta, 1901) was the result of an Italy-wide research project carried out in 1896-1900 by the geographer Mario Baratta with the help of a large network of collaborators (mainly librarians and seismologists). Baratta personally conducted research in the UCMG library and the main libraries of Rome, Naples, Milan and Pavia, while his collaborators sifted through local histories relevant to their locations to compile chronological earthquake lists from which Baratta would select the items to be included in his compilation.

Baratta's personal archive was lost shortly after his death in 1935; the full list of his collaborators is unknown, and it is hard to tell how much each contributed to the general effort. The reference list appended to Baratta (1901) shows more than $25 \%$ of the listed earthquakes to be derived from previous earthquake compilations (Pilla, 1846; Perrey, 1848; Guarini, 1880; Mercalli, 1883; Piovene, 1888, Tommasi, 1888, De Rossi, 1889; Baratta, 1897; Mercalli, 1897a,b; Baratta, 1899; Benassi, 1899, etc; for a complete list see Guidoboni, 2000), and the rest from historical compilations, standard collections of printed historical sources, scientific literature and - in a few cases - seismological bulletins. In other words, Baratta (1901) is almost entirely based on historical and seismological compilations, mostly of a local and regional nature. Providing as it does a sort of rounding up of past earthquake knowledge, 


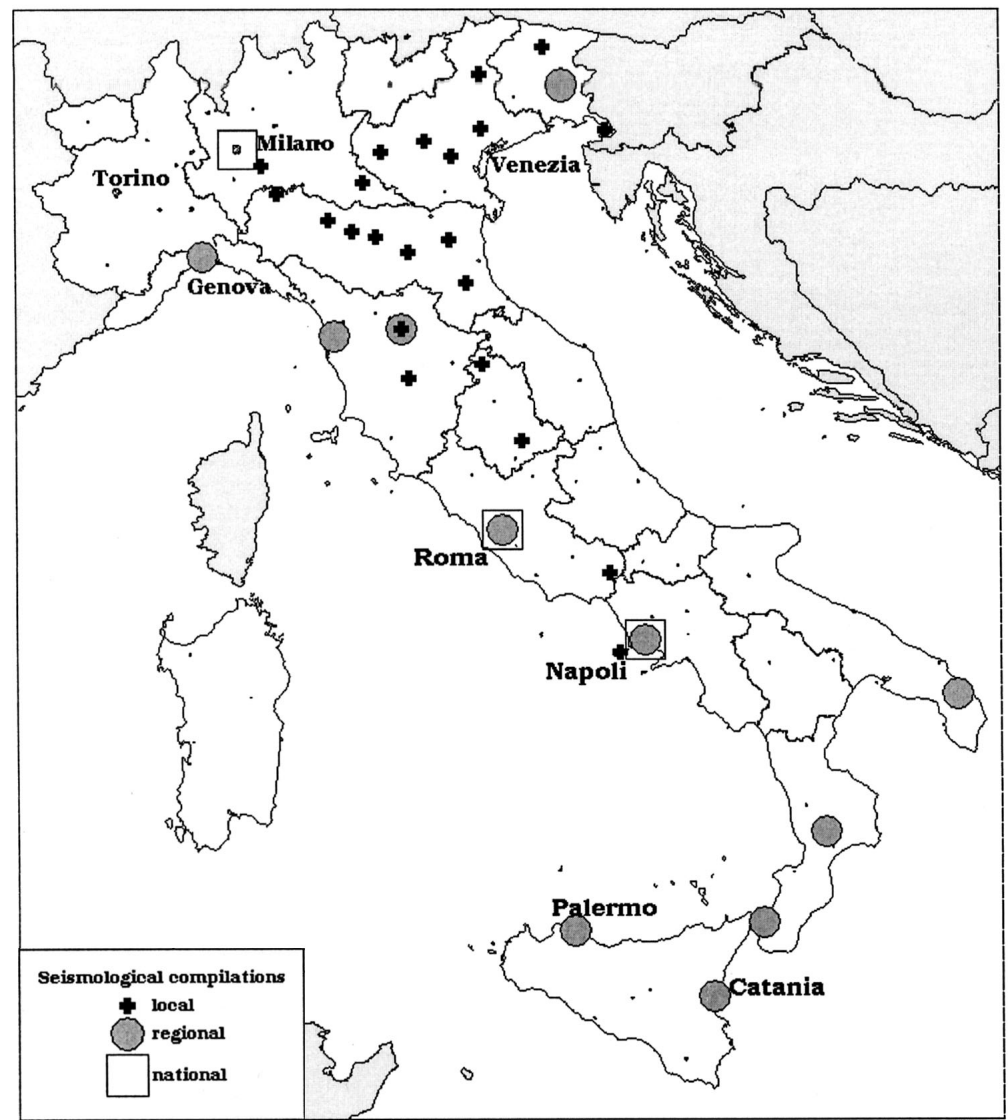

Fig. 1. Geographical distribution of Italian seismological compilation from Bonito (1691) to Baratta (1901).

Baratta (1901) stands as a watershed in Italian seismology, and played a key role in the establishment of Italy's «earthquake consciousness». More than a century after its publication, and despite having been found wrong on very many occasions, this volume remains an authority Italian historical seismologists have still to reckon with and still cannot do without.

\subsection{The decline of the practice of systematic observation}

The First World War put an end to the practice of collecting reports of earthquakes by the
Geodynamic Service and started the slow but inexorable decline of state-sponsored earthquake monitoring activities. From 1913 to 1943 the Geodynamic Service continued to publish summaries of its seismic data (lists of affected localities and related intensities) in a succession of scientific magazines (table II) but this activity did not survive the upheaval of the Second World War. The original data collected by UCMG (seismic questionnaires and related papers, letters, newspaper cuttings etc.) are today held partly by the National Institute for Geophysics and Vulcanology (INGV), and partly by the Central Office for Agrarian Ecology (UCEA, former UCMG). 
Table II. Main seismological bulletins published in Italy from 1874 to 1943.

\begin{tabular}{lc}
\hline \hline \multicolumn{1}{c}{ Title } & Time span \\
\hline $\begin{array}{l}\text { Bullettino del Vulcanismo Italiano, voll. I (1874) - XX (1897), Roma } \\
\text { Notizie sismiche pervenute..., supplemento al Bollettino Meteorico } \\
\text { Giornaliero, Ufficio Centrale di Meteorologia, Roma }\end{array}$ & $1874-1894$ \\
$\begin{array}{l}\text { Notizie sui terremoti osservati in Italia durante l'anno..., Appendice } \\
\text { al Bollettino della Società Sismologica Italiana, Roma, Modena }\end{array}$ & $1887-1894$ \\
$\begin{array}{l}\text { Macrosismi avvertiti in Italia nell'anno..., Bollettino della Società } \\
\text { Sismologica Italiana, Roma }\end{array}$ & $1895-1913$ \\
$\begin{array}{l}\text { Bollettino Sismico, Ufficio Centrale di Meteorologia e Geofisica, } \\
\text { Roma, fasc. II Macrosismi }\end{array}$ & $1916-1926$ \\
$\begin{array}{l}\text { Bollettino Sismico Settimanale, Ufficio Centrale di Meteorologia e } \\
\text { Geofisica, Roma }\end{array}$ & $1917-1936$ \\
$\begin{array}{l}\text { Notizie sismiche, Bollettino della Società Sismologica Italiana, } \\
\text { XXXIII(1935) - XXXVII(1939), Roma }\end{array}$ & $1917-1943$ \\
\hline
\end{tabular}

\subsection{The decade of parameters (1970s)}

In the early 1970s Italian seismologists and geologists started compiling parametric earthquake catalogues for hazard estimation purposes, on a regional (Carrozzo et al., 1975; Bernardis et al., 1978; Iaccarino and Molin, 1978; Magri and Molin, 1979; Barbano et al., 1980; Dell'Olio e Molin, 1980; Molin, 1981; Margottini and Molin, 1983; OGS, 1987) and national scale (Carrozzo et al., 1973) (fig. 2). Some of these catalogues were unpublished, their use being restricted to the various Italian institutions that sponsored their compilation. Their focal parameters were mostly derived from previous seismological compilations, barring a few instances of slightly more complex studies funded by the Italian National Nuclear Energy Committee (CNEN, afterwards ENEA) for selected areas (Friuli, Latium, Basilicata). Generally these studies consisted in a «critical» re-assessment of information miscellaneously derived from seismological compilations, local historiography, 19th century newspapers and seismological bulletins.

\section{The first modern published Italian catalogue (1985)}

One of these catalogues, compiled on behalf of the Italian Electricity Agency (ENEL, 1978), provided the starting point for the first modern systematic revision of Italian earthquakes, undertaken after the destructive Irpinia earthquake of 1980 by the «Catalogue Working Group» of the Progetto Finalizzato Geodinamica (PFG) of the National Research Council (CNR), under the chairmanship of Daniele Postpischl. The Working Group's aim was producing a revised national parametric earthquake catalogue and detailed studies of the major Italian historical earthquakes. This experience was seminal in introducing the involved researchers to the complexities of historical research and fostering their appreciation of its practical uses. Some contented themselves with retrieving and appraising a few original sources quoted by seismological compilations; others attempted wider-ranging bibliographical searches; a few enlisted the help of professional historians to make the first attempts at full-blown historical earthquake investigation, applying the methods of historical criticism to primary historical sources. The variety of these experiences was reflected in the broad spectrum of quality shown by the output of the PFG project, which led to the publication of 81 monograph studies comprising in all about 6300 intensity datapoints (Postpischl, 1985a), and the Postpischl (1985b) catalogue.

The Postpischl (1985b) catalogue was compiled by carefully collating the ENEL 
(1978) catalogue with several other national/local parametric catalogues and the Postpischl (1985a) studies (fig. 3). It has the paramount merit of being a published catalogue (the previous ones were all meant for restricted use only, or available only to scientific institutions), making available for general use no less than 37000 earthquake records. On the reverse side, like most early parametric catalogues, it is very inhomogeneous (the increase in quantity of records having been paid for in terms of lowered quality), it includes many duplications and quite a few events which further research has later shown to be fictitious. Finally, the procedures used for assessing earthquake parameters are far from transparent. For example, the «intensity»parameter is intended to be Imax, but sometimes it is derived as $I_{0}$ from isoseismal lines. The declared scale is Mercalli-Cancani-Sieberg (MCS), but in fact several of the parametric catalogues inserted in the Postpischl catalogue used the Medvedev-Sponheuer-Karník (MSK) scale. The Postpischl catalogue generally takes its macroseismic magnitudes from the ENEL catalogue, which derived them from intensity using Karník's (1969) relation. For several recent earthquakes the Postpischl catalogue also reports $M_{L}$ magnitudes, derived either from bulletins or from one of the main quoted sources.

The Postpischl (1985b) catalogue (again, like all parametric catalogues of its generation) is derived largely from the parameterisation of 19th century seismological compilations, and primarily from Baratta (1901). In fact, an analysis of the Postpischl (1985b) catalogue for the time-window prior to 1900 and the epicentral intensity threshold $I_{0} \geq \mathrm{V}$-VI MCS (table III) shows that more than $50 \%$ of the entries derive from Baratta (1901). As most of the parametric catalogues merged in the Postpischl cat-

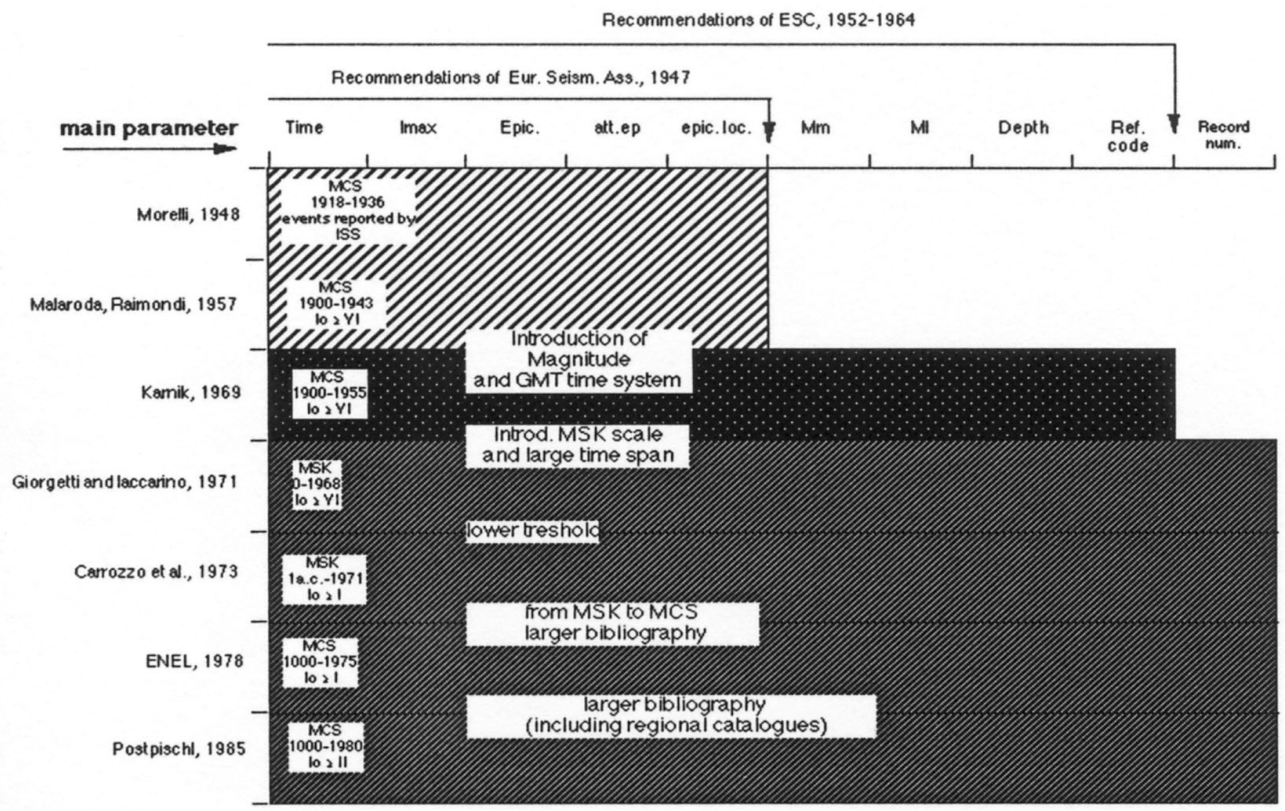

Fig. 2. Main characteristics of Italian parametric earthquake catalogues from 1948 to 1985: the turning point is the publication of the Karník catalogue which introduced a magnitude parameter. The type of macroseismic scale used (MCS or MSK) is not clearly reported, so in the Postpischl catalogue it comes out mixed. 


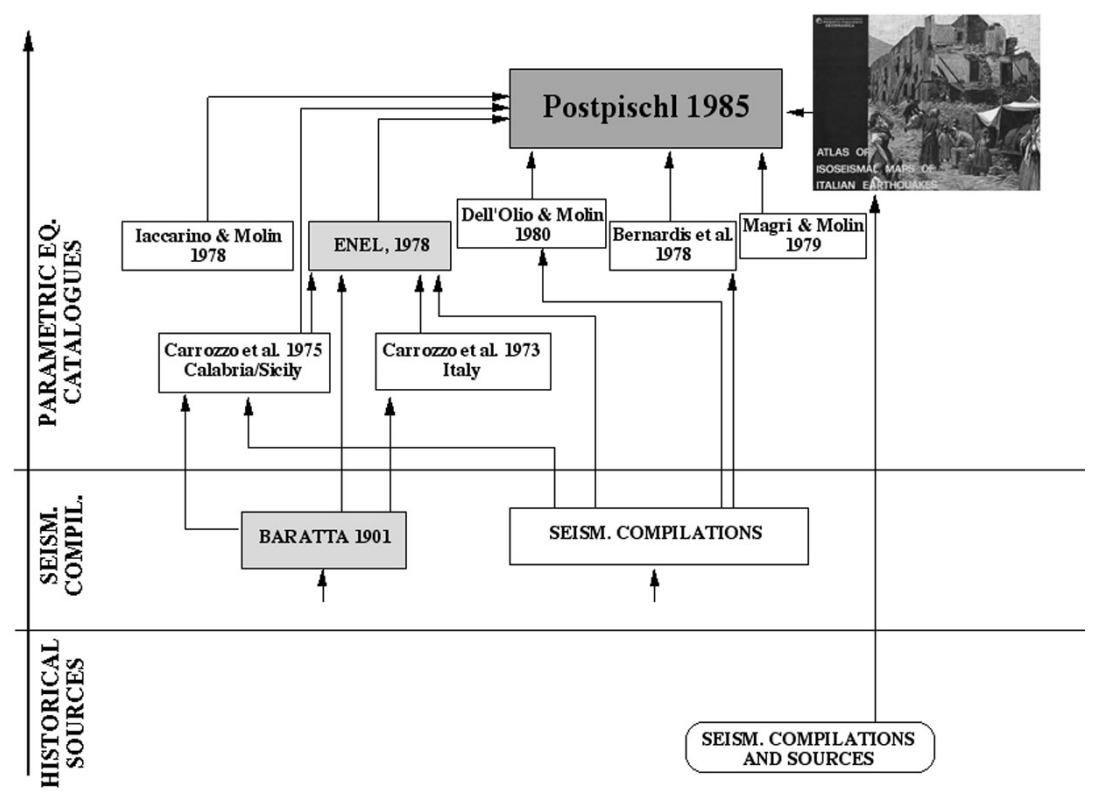

Fig. 3. Simplified filiation scheme of the Postpischl (1985b) catalogue.

Table III. Analysis of the background of the Postpischl (1985b) catalogue (time window 1000-1899, $I_{0} \geq 5.5$ ); the reference code analysed is the main one when multiple roots are available.

\begin{tabular}{ccc}
\hline \hline Reference & Entries & Percentage \\
\hline $\begin{array}{c}\text { Baratta (1901) } \\
\begin{array}{c}\text { Other compilations } \\
\text { known and quoted } \\
\text { by Baratta (1901) }\end{array}\end{array}$ & 1195 & $51 \%$ \\
Other & 137 & $6 \%$ \\
parametric \\
catalogues
\end{tabular}

alogue derive from Baratta (1901) too (or from similar compilations), it can be concluded that approximately $96 \%$ of the entries are supported by Baratta (1901), and only about $2 \%$ by recent studies based on the critical revision of historiography and primary historical sources.

\section{The growth of historical seismology (1985-2000)}

The first project of extensive historical investigation dealing with some thousands of earthquakes and involving academically trained 
historians was carried out in 1983-1987 in the frame of an ENEL-sponsored feasibility study for the study of sites for the building of nuclear power plants. This project, led by the former coordinating unit of the PFG Catalogue Working Group (established as SGA), and supported by about a hundred historians, focused on low seismicity areas (Southern Piedmont, the Po valley and the Salento peninsula). From 1988, the National Institute of Geophysics (ING) assumed the sponsorship of the project, setting as its goal the revision of all strong Italian earthquakes.

This study was carefully planned, taking into account the historical features and historical source potential of all areas potentially shaken by the earthquakes to be investigated. Though carried out, in the main, by earthquake, extensive investigations by source were also made in several archives and libraries (mainly for the ancient and medieval periods). This allowed the acquisition of detailed knowledge of many kinds of sources, essential for the correct interpretation of historical records. All investigations should have been performed according to a preset standard and were co-ordinated by a single managing team. The collected historical records were compiled according to a pre-set pattern that allowed them to be inserted in a databank.

The main outcomes of this project were a collection of studies on Mediterranean earthquakes before 1000 A.D. (Guidoboni, 1989; Guidoboni et al., 1994) and the first edition of the Catalogue of Strong Italian Earthquakes (Boschi et al., 1995), a modern database (on CD-ROM) providing studies on 346 major earthquakes, supported by a large bibliography and (in some cases) by transcriptions of original sources. The second edition (Boschi et al., 1997) provided studies for 559 earthquakes (including some updates on the 1995 issue). The third edition (Boschi et al., 2000), published as a special issue of the journal Annali di Geofisi$c a$, provides studies for fifty more earthquakes (mostly located in the Northern and UmbroMarchesan Apennines) and several updates of studies included in the previous issues, but unfortunately no transcriptions of original sources. In the last few years the research group responsible also published monographs dealing with the seismic history of Italian regions
(Boschi et al., 1998) and towns (Boschi and Guidoboni, 2001, 2003).

A sister project was undertaken in 1986 by the National Group for Protection against Earthquakes (GNDT), then attached to the Italian Council for National Research (CNR), now a branch of the National Institute of Geophysics and Vulcanology (INGV). This was the launch of a five-yearly «Macroseismic project» involving a large number of academically-trained historians, some as full-time investigators, and others as members of university research units provided with ad-hoc grants. The project aimed to prepare: i) in-depth studies of a selection of earthquakes each of which was a «key event» for hazard assessment in a given moderately seismic area; ii) standard and homogeneous preliminary studies of all earthquakes listed by the Postpischl (1985b) catalogue with $I_{0} \geq$ VIIVIII MCS; iii) a database of macroseismic data and a parametric catalogue specifically designed for hazard purposes. Some of the earthquakes concerned had already been studied by various agencies after 1980, and intensity points had been assessed for them. However, no less than 600 of these earthquakes had never been studied and no intensity points were extant for them. All the available earthquake studies were retrieved and the intensity data they provided were re-compiled in a standard format. The 600 earthquakes without intensity points were studied for the first time ever. At the end of the work, a careful analysis of the macroseismic procedures employed was also made, to point out weaknesses and suggesting possible solutions (Stucchi and Albini, 1991).

The resulting «NT» catalogue was first released as a working file in 1993 (Stucchi et al., 1993) and published in 1997 (Camassi and Stucchi, 1997a). In 1998 an updated version of the catalogue was made available online (http://emidius.mi.ingv.it/NT/) together with the whole Database of Macroseismic Observations «DOM» (Monachesi and Stucchi, 1997), which includes more than 36000 datapoints relating to 1000 damaging Italian earthquakes (http://emidius.mi.ingv.it/DOM/). The NT4.1 and DOM web pages, still existing and widely used by researchers, allow users to download data, to query the catalogue and the database in 
different ways and to plot the observed seismic history for about 2000 localities.

From 1989 to 1992 the GNDT research group was also the leading team of the EC project RHISE (Review of Historical Seismicity in Europe), co-ordinated by M. Stucchi (Stucchi, 1993b), whose output is available both in book form (Stucchi, 1993a, Albini and Moroni, 1994) and online (http://mi.ingv.it/RHISE/ home.html). From 1995 to 1998 the same team led the EC project BEECD (Basic European Earthquake Catalogue and Data Base), which led to the preparation of an European Macroseismic database and to a detailed analysis of the problems to be expected when merging together different kinds of catalogues or intensity data sets produced by several authors and in variable contexts (Camassi and Stucchi, 1997b; Albini and Stucchi, 1997).

During this period, valuable studies of historical earthquakes have also been performed by other teams and institutions. The Vesuvian Observatory (now an INGV department) published an outstanding study of the 1456 earthquake (Figliuolo, 1988), one of the largest that ever affected the Italian peninsula, and whose main characteristics (as reconstructed by Meletti et al., 1988) stimulated seismologists to speculate on its possibly being a sequence of multiple, sub-contemporary earthquakes, the assessment of whose focal parameters requires special care. The same team also recently published a study of Southern Italy Early Medieval earthquakes (Figliuolo and Marturano, 2002) The National Seismic Survey (SSN) published monumental monographs of some major 19th-20th century earthquakes (Castenetto et al., 1998; Castenetto and Galadini, 1999; Castenetto and Sebastiano, 2002).

In 1999 the «CPTI» catalogue (Working Group CPTI, 1999) was published, which is an updated version of NT4.1, compiled with the agreement of the whole Italian seismological community as embodied in GNDT, ING(V) and SSN.

\section{The historical background of the current Italian catalogue}

The Italian seismic catalogue can boast of what is probably the best historical back- ground of any. The matchless wealth of the Italian historical documentary patrimony and the frequency with which destructive earthquakes have affected the Italian territory in historical times are the two mainsprings for the age-old Italian tradition of historical-seismological studies (Guidoboni and Stucchi, 1993; Guidoboni et al., 1994). As Guidoboni et al. (1994) points out, it is possible to find comparatively well documented earthquakes as far back in time as the 6th century B.C., thanks to evidence available in several kinds of sources, epigraphical, literary and archaeological (Guidoboni, 2000). Between the 8th century A.D. and the 15 th century the main sources of information are at first somewhat limited, and mostly of a narrative kind (annals and chronicles). But with the passing of time, they steadily grow more detailed, varied in kind, and abundant in numbers, embracing the administrative records of city-states and the Church, and numerous serial sources of remarkable consistency, such as chronicles and diaries. During the first half of the 16th century the earliest newsletter networks come into being, in the shape of manuscript reports («Avvisi») exchanged between several Italian and European courts. The first half of the 17th century sees also the birth of the modern printed gazettes (Camassi and Caracciolo, 1994; Camassi and Castelli, 2004), connected in a network whose main nodes are Rome, Florence, Bologna, Mantova, Genoa, Venice and Milan.

Selling news becomes a profitable activity in the 18th and 19th centuries and the popularity of printed gazettes is testified by the preservation of large collections in Italian libraries and archives.

In the second half of the 19th century, as was previously mentioned, the creation of national meteorological and seismological networks lead to the building up of a large amount of macroseismic observations, which to this day has still to be exploited fully. After the drastic decline of earthquake investigation caused by the Second World War, and perpetuated during the 1960s and 1970s, the activities started by the PFG project in the 1980s represents a «new birth» of the Italian tradition of seismological studies. 


\section{What next?}

In the last twenty-odd years, the contribution made by Italian historical-seismological studies to general earthquake knowledge has taken two main directions. Advanced historical investigations have been made available for a large number of earthquakes (1070 in the CPTI catalogue, out of a total of 2480 entries). All the strongest Italian earthquakes are now supported by recent historical investigations and intensity data (fig. 4). Furthermore, approximately 250 fictitious earthquakes have been detected and «put away» (such fakes are present in quantity both in the «classical» earthquake compilations and in the first generation of parametric earthquake catalogues).
However, the bulk of the current parametric catalogue still remains to some extent a reflection of the complex historical-seismological tradition of earthquake compilations summarised by Baratta (1901). Most of the CPTI catalogue entries for the time window up to 1899 are those known to Baratta (1901), and in quite a few cases recent research - however careful and well-balanced - has not been able either to alter or to improve the pattern of information already made available by Baratta (1901). These facts have an evident bearing on the assessment of catalogue completeness, which is a significant question for hazard estimation. As already mentioned, Baratta (1901) was a huge collector of data, mostly derived from previous historical and seismological

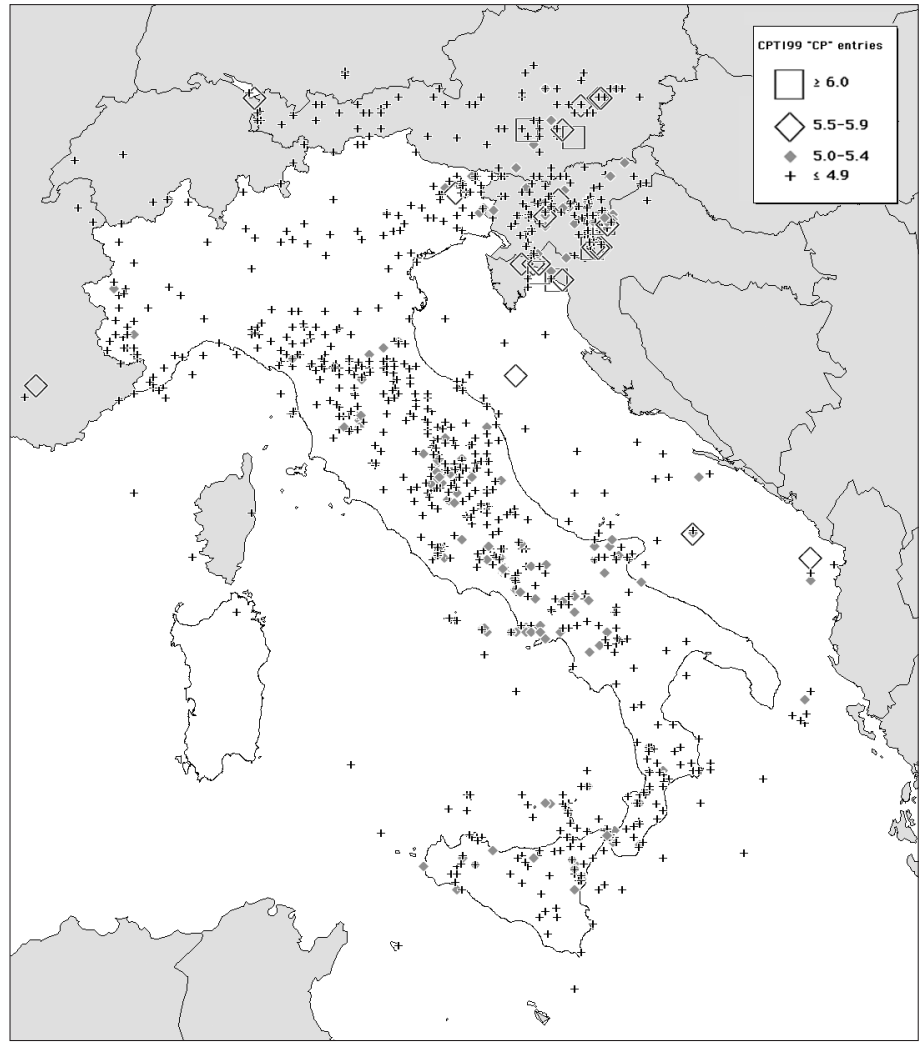

Fig. 4. Distribution of entries in CPTI catalogue (Working Group CPTI, 1999) without a supporting dataset: all 22 earthquakes with $M \geq 5.5$ are located in the border part of the space window covered by the catalogue. 


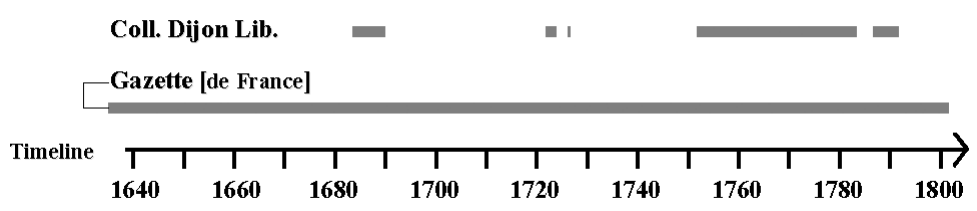

Fig. 5. Time-coverage of the Gazette de France collection perused by Alexis Perrey (1848) compared with the collection actually available.

compilations of a local character. The geographical distribution of the main historical and seismological compilations from which Baratta drew his raw data (see fig. 1) gives at least a rough idea of the coverage they afford for the different parts of Italy. Their density is remarkably higher in northern and (up to a point) cen-

Table IV. Number of earthquakes in the CPTI catalogue (Working Group CPTI, 1999) and number of intensity data points in the corresponding database.

\begin{tabular}{ccc}
\hline \hline Time Period & $\begin{array}{c}\text { CPTI } \\
\text { catalogue }\end{array}$ & $\begin{array}{c}\text { CPTI } \\
\text { database }\end{array}$ \\
\hline$<1000$ & 24 & 54 \\
$1000-1099$ & 5 & 16 \\
$1100-1199$ & 15 & 127 \\
$1200-1299$ & 28 & 131 \\
$1300-1399$ & 51 & 229 \\
$1400-1499$ & 70 & 385 \\
$1500-1599$ & 103 & 489 \\
$1600-1699$ & 130 & 1732 \\
$1700-1799$ & 262 & 3146 \\
$1800-1850$ & 185 & 2064 \\
$1851-1899$ & 450 & 8603 \\
$1900-1963$ & 878 & 19917 \\
$1964-1992$ & 279 & 16640 \\
Total & 2480 & 53533 \\
\hline
\end{tabular}

tral Italy than in southern Italy. Another factor which deeply impaired the level of completeness achieved by Baratta's work was the lack of a systematic approach to the study of serial sources, especially gazettes and newspapers. This is true equally of Baratta and the 19th century compilations on which he relied most heavily (Perrey, 1848; De Rossi, 1889; Baratta, 1899). In this regard, it is interesting to note that these studies were doomed from the start by their use of incomplete collections of gazettes and newspapers in the first place (fig. 5).

It is a legitimate assumption that if the current catalogue is (and it is), on the whole, a faithful mirror of Baratta (1901), and through it of the «seismological tradition» embodied in the pre-Baratta compilations, it cannot avoid being affected by the same faults and lacunae. It is therefore advisable to devise specific strategies aimed at detecting those earthquakes that have remained until now «unknown» to the seismological tradition (Camassi and Castelli, 2004).

\section{Conclusions}

After twenty years of historical research a large amount of historical-seismological data is now available in Italy, most of it published or made available in public databases. The database which supports the CPTI catalogue contains more then 50000 intensity data points $(\approx 11000$ prior to 1880 , table IV) assessed in a rather homogeneous way on the basis of historical sources, most of them primary.

Recent Italian earthquake catalogues can rely on a good basis of macroseismic data and have adopted clearer and more transparent 
procedures in the parameterisation of historical records.

The NT4.1 catalogue (Camassi and Stucchi, 1997a) derives its parameters from intensity data points for about 1000 earthquakes; the procedures adopted for deriving parameters from intensity data are not particularly sophisticated, but they are at least clearly expressed. The main magnitude provided is $M_{s}$, which can be observed or calculated from Io or from other kinds of magnitude $\left(M_{L}, m_{b}\right)$.

The CPTI catalogue (Working Group CPTI, 1999), adopting the Gasperini and Ferrari (2000) parameterisation method, represents a significant advance in the formalisation of the procedures for the definition of parameters, which, for the first time ever, are reproducible.

Today seismologists are submitting new questions to historical seismology and new research perspectives are in progress, on catalogue completeness, apparently silent areas, minor earthquakes, unknown earthquakes, etc., involving also new disciplines, as in the fields of archaeoseismology and paleoseismology.

\section{Acknowledgements}

The author wish to thank V. Castelli, the two reviewers and the editors for their careful revision of the manuscript and their suggestions.

\section{REFERENCES}

Albini, P. and A. Moroni (Editors) (1994): Historical Investigation of European Earthquakes, Materials of the CEC Project «Review of Historical Seismicity in Europe»(CNR, Milano), vol. 2, pp. 254

Albini, P. and M. Stucchi (1997): A Basic European Earthquake Catalogue and a Dtabase for the evaluation of long-term seismicity and seismic hazard (BEECD), in Seismic risk in the European Union, edited by A. GHAZI and M. YEROYANNI (Brussel-Luxembourg), vol. I, 53-77.

BARATTA, M. (1897): Materiali per un catalogo dei fenomeni sismici avvenuti in Italia (1800-1872), Mem. Soc. Geogr. Ital., VII, 81-164.

BaratTA, M. (1899): Saggio dei materiali per una storia de fenomeni sismici avvenuti in Italia raccolti dal Prof Michele Stefano de Rossi, Boll. Soc. Geol. Ital., XVIII, 432-460

BARATTA, M. (1901): I terremoti d'Italia. Saggio di storia geografia e bibliografia sismica italiana, Torino, pp. 951.
Barbano, M.S., M. Cosentino, G. Lombardo and G. PATANÉ (1980): Isoseismal Maps of Calabria and Sicily Earthquakes (Southern Italy) (CNR-PFG, Catania), pp. 116.

Benassi, P. (1899): Materiali per la Storia dei Fenomeni Sismici della Regione Parmense, Parma, pp. 135.

Bernardis, G., R. Bartole, F. Giorgetti, D. Nieto and M. Russi (1978): Earthquake catalogue of Friuli-Venezia Giulia region from Roman epoch up to 1976, Boll. Geofis. Teor. Appl., 18, 300-334.

Bonito, M. (1691): Terra tremante overo continuatione de, terremoti dalla creatione del mondo sino al tempo presente, Napoli, pp. 822.

Boschi, E. and E. Guidoboni (2001): Catania Terremoti e Lave dal Mondo Antico alla Fine del Novecento (INGV Roma-SGA, Bologna), pp. 414

Boschi, E. and E. GuIDoBoni (2003): I Terremoti a Bologna e nel suo Territorio dal XII al XX Secolo (INGV RomaSGA Bologna), pp. 597.

Boschi, E., G. Ferrari, P. Gasperini, E. Guidoboni, G. SMriglio and G. VAlensise (1995): Catalogo dei Forti Terremoti in Italia dal 461 a.C. al 1980 (ING RomaSGA Bologna), pp. 973.

Boschi, E., E. Guidoboni, G. Ferrari, D. Mariotti, G. VAlENSISE and P. GASPERINI (Editors) (2000): Catalogue of Strong Italian Earthquakes from 461 B.C. to 1980, Ann. Geofis., 43 (4), 609-868.

Boschi, E., E. Guidoboni, G. Ferrari and G. Valensise (1998): I terremoti dell'Appennino Umbro-Marchigiano, Area sud orientale dal 99 a.C. al 1984 (INGV Roma-SGA, Bologna), pp. 267.

Boschi, E., E. Guidoboni, G. Ferrari, G. Valensise and P. GASPERINI (1997): Catalogo dei Forti Terremoti in Italia dal 461 a.C. al 1990 (ING Roma-SGA, Bologna), pp. 644

CAMAssi, R. (1991): Bollettini sismici e studio dei terremoti dei secoli XIX e XX, in GNDT, Atti del Convegno, Pisa, 25-27 giugno 1990, edited by P. Albini and M.S. BARBAno, Macrosismica, Bologna, 2, 207-222.

CAMAssi, R. and C. CARACCIOLO (1994): The gazette «Bologna»: an observer of European natural events in the early 18th century, in Historical Investigation of European Earthquakes, Materials of the CEC project «Review of Historical Seismicity in Europe», edited by $\mathrm{P}$. Albini and A. Moroni (CNR, Milano), vol. 2, 153-162.

CAmassi, R and V. CASTElli (2004): Looking for new earthquake data in the 17th-18th century European «newssellers» network, J. Earthquake Eng., 8 (3), 335359.

CAMASsi, R. and M. STUCCHI (1997a): NT4.1, un catalogo Parametrico di Terremoti di Area Italiana al di Sopra della Soglia del Danno (GNDT, Milano), pp. 95 (on line: http://emidius.mi.ingv.it/NT/home.html).

Camassi, R. and M. Stucchi (1997b): Building up a parametric earthquake catalogue in Europe: the historical background, in Historical and prehistorical earthquakes in the Caucasus (Dordrecht), edited by D. GIARDINI, NATO ASI Series, 2 Environment, 28, 357-374.

Carrozzo, M.T., G. De Visintini, F. Giorgetti and E. IaCCARINO (1973): General Catalogue of Italian earthquakes, CNEN, RT/PROT (73) 12, Roma.

Carrozzo, M.T., M. Cosentino, A. Ferlito, F. Giorgetti, G. PAtANÉ and M. RiUscetti (1975): Earthquakes cata- 
logue of Calabria and Sicily (1783-1973), Quad. Ric. Scient., 93, Roma.

Castenetto, S. and F. Galadini (Editors) (1999): 13 Gennaio 1915. Il Terremoto nella Marsica, (SSN-IRTR Roma), pp. 788.

Castenetto, S. and M. Sebastiano (Editors) (2002): Il «Terremoto del Vulture» 23 Luglio 1930 VIII dell'Era Fascista, (SSN-DPC Roma), pp. 349.

Castenetto, S., E. Cubellis and M. Rebuffat (Editors) (1998): Il Terremoto del 28 Luglio 1883 a Casamicciola nell'Isola d'Ischia, (SSN Roma), pp. 332.

Da Secinara, F. (1652): Trattato Universale di Tutti i Terremoti Occorsi, e Noti nel Mondo con li Casi Infausti ed Infelici Presagiti da Tali Terremoti ecc., L'Aquila.

DE Rossi, M.S. (Editor) (1889): Documenti raccolti dal defunto conte Antonio Malvasia per la storia dei terremoti ed eruzioni vulcaniche massime d'Italia, Mem. Pontificia Accad. Nuovi Lincei, Roma, V, 169-289.

Dell'Olio, A. and D. Molin (1980): Catalogo Macrosismico del Lazio dall'Anno 1000 al 1975, ENEA, Internal Report, pp. 143.

ENEL (1978): Catalogo dei terremoti italiani dall'anno 1000 al 1975 (compiled by Geotecneco Spa, Roma), (computer printout)

FERRARI, G. (Editor) (1992): Two Hundred Years of Seismic Instruments in Italy 1731-1940, Bologna.

Figliuolo, B. (1988): Il terremoto del 1456, Storia e Scienze della Terra, I (Edizioni Studi Storici Meridionali, Nocera Inferiore).

Figliuolo, B and A. Marturano (2002): Terremoti in Italia Meridionale dal IX all'XI secolo, in Contributi per la storia dei terremoti nel bacino del Mediterraneo (secc. $V$-XVIII), edited by A. Marturano, Salerno, 3367.

GASPERINI, P. and G. FERRARI (2000): Deriving numerical estimates from descriptive information: the computation of earthquakes parameters, Ann. Geofis., 43 (4), 729-746.

GioRGETTI, F. and E. IACCARINO (1971): Italian Earthquake Catalogue from the Beginning of the Christian Age up to 1968, Boll. Geofis. Teor. Appl., XIII, pp. 113.

GuARINI, F. (1880): I terremoti a Forlì in Varie Epoche, Memorie Cronologiche, Forlì, pp. 161

Guidoboni, E. (Editor) (1989): I Terremoti Prima del Mille, Storia Archeologia Sismologia, Bologna.

Guidoboni, E. (2000): Method of investigation, typology and taxonomy of the basic data: navigating between seismic effects and historical context, Ann. Geofis., 43 (4), 621-666

Guidoboni, E. and M. STUCCHI (1993): The contribution of Historical Records of Earthquakes to the Evaluation of Seismic Hazard, Ann. Geofis., XXXVI (3-4), 201-215.

Guidoboni, E., A. Comastri and G. Traina (1994): Catalogue of Ancient Earthquakes in the Mediterranean Area up to the 10th Century (ING, Roma-SGA, Bologna), pp. 504.

Hoff, K.E.A. vON (1840-1841): Chronik der Erdbeben und Vulcan-Ausbrüche, I. Theil (Justus Perthes, Gotha), pp. 470; II. Theil (Justus Perthes, Gotha), pp. 406.

IACCARINO, E. and D. Molin (1978): Raccolta di notizie macrosismiche dell'Italia Nordorientale dall'anno 0 all'aprile 1976, CNEN, RT/DISP (78) 7, pp. 63

KARNIK, V. (1969): Seismicity of the European area, Part I (D. Reidel Publ. Comp., Dordrecht, Holland), pp. 220.
KisPatic, M. (1891-1892): Potresi u Hrvatskoj, Rad. Jugosl. Akademje Znanosti i Umjetnosti, CVII, 81-164; CIX, $1-79$.

Ligorio P. (1574): Libro, o Trattato, de Diversi Terremoti, Raccolti da Diversi Autori, per Pyrro Ligorio Cittadino Romano, Mentre la Città di Ferrara, è Stata Percossa et ha Tremato per un Simile Accidente dal Moto della Terra, Archivio di Stato di Torino, Antichità Romane, cod. 28.

MAGRI, G. and D. Molin (1979): Attività Macrosismica in Basilicata, Campania e Puglia dal 1847 al 1861, CNEN $R T / A M B$ (79) 5 , pp. 104.

Malaroda, R and C. RAIMONDI (1957): Linee di dislocazione e sismicità in Italia, Bollettino di Geodesia e Scienze Affini, 16 (3), 273-323.

Mallet, R. (1853): Catalogue of recorded earthquakes from 1606 B.C. to 1850 , Brit. Ass. Rep., 1853, 1-176.

MALLET, R. (1854): Catalogue of recorded earthquakes from 1606 B.C. to 1850 , Brit. Ass. Rep., 1854, 118-213.

Mallet, R. (1855): Catalogue of recorded earthquakes from 1606 B.C. to 1850 , Brit. Ass. Rep., 1855, 2-326.

ManetTi, G. (1457): De terraemotu Libri tres (edited by C. SCOPELliti and D. Molin, Roma, 1983).

Margottini, C. and D. Molin (1983): Risultati Preliminari delle Ricerche di Sismica Storica Condotte nell' Appennino Tosco-Emiliano, ENEA, PAS-ISP BR, (83) 2, Roma.

Meletti, C., E. Patacca, P. Scandone and B. Figliuolo (1988): Il terremoto del 1456 e la sua interpretazione nel quadro sismotettonico dell'Appennino meridionale, in Il Terremoto del 1456. Storia e Scienze della Terra, edited by B. Figliuolo (Edizioni Studi Storici Meridionali, Nocera Inferiore), I, 71-108.

Mercalli, G. (1883): Vulcani e Fenomeni Vulcanici in Italia, Milano (reprint, Bologna 1981), pp. 374.

Mercalli, G. (1897a): I Terremoti della Liguria e del Piemonte, Memoria con tre tavole in litografia, Napoli, pp. 146.

MerCAlli, G. (1897b): I terremoti della Calabria meridionale e del messinese, Mem. Soc. Ital. Sci. (detta dei XL), III, (11), Roma, 117-266.

Molin, D. (1981): Sulla Sismicità Storica dei Colli Albani, CNEN/RT/AMB (81) 11, Roma.

MonACHESI, G. and M. STUCCHI (1997): DOM4.1, un database di osservazioni macrosismiche di terremoti di area italiana al di sopra della soglia del danno, GNDT, Internal Report, Milano-Macerata, (on line: http://emidius.mi.ingv.it/DOM/ home.html).

Mongitore, A. (Editor) (1743): Istoria cronologica de' terremoti di Sicilia, in Della Sicilia Ricercata nelle Cose più Memorabili, 2, 345-445.

Morelli, C. (1948): Contributo allo Studio dei Microsismi (ING, Roma), pp. 32.

Ogs (1987): Alpor: Catalogo delle Alpi Orientali, Trieste (computer printout)

PACCA C. (1563): Discorso del Terremoto, Biblioteca della Società Napoletana di Storia Patria, Sismica ms. 7/A3

Pauly, A. and G. Wissowa (1949): Realenzyclopaedie der classischen Altertumswissenschaft, 18.3, «Paradoxographoi», 1137-1166.

Perrey, A. (1848): Mémoire sur les tremblements de terre de la peninsule Italique, Mémoires couronnés et mémoires des savant étrangers, Academie Royale de Belgique, XXII, 1-144. 
PILla, L. (1846): Principali Tremuoti Avvenuti in Tempi storici in Toscana, in Istoria del Tremuoto che ha Devastato i Paesi della Costa Toscana il dì 14 Agosto 1846, Pisa, 195-217.

Piovene, G. (1888): Cronaca dei terremoti a Vicenza, Roma, Ann. Uff. Cent. Meteorol. Geodin. Ital., II (8), 46-57.

PostPISCHL, D. (Editor) (1985a): Atlas of isoseismal maps of Italian earthquakes, Quad. Ric. Sci., Bologna, 114 (2A).

PostPIschl, D. (1985b): Catalogo dei terremoti Italiani dall'anno 1000 al 1980, Quad. Ric. Sci., Bologna, 114 (2B), pp. 239.

SCHMIDT, JFJ (1879): Studien über Erdbeben, Leipzig, pp. 360.

SoldANI, A. (1798): Relazione del Terremoto Accaduto in Siena il dì 26 Maggio 1798 Divisa in Sei lettere, Siena, pp. 98

Stucchi, M. (Editor) (1993a): Historical Investigation of European Earthquakes (CNR, Milano), vol. 1, pp. 258.

STUCCHI, M. (1993b): Through catalogues and historical records: an introduction to the project «Review of Historical Seismicity in Europe», in Historical Investigation of European Earthquakes, edited by M. STUCCHI (CNR, Milano), vol. 1, 3-14.

Stucchi, M. and P. Albini (1991): New developments in Macroseismic Investigation, in Proc. CENAPRED-EC International Workshop on «Seismology and Earthquake Engineering», edited by E. FACCIOLI, and R. Meli, Mexico City, 22-26 April 1991, 47-70.

Stucchi, M., R. Camassi and G. Monachesi (1993): NT: un Catalogo «di Lavoro» del GNDT, Milano, pp. 85.

TommAsi, A. (1888): I terremoti nel Friuli dal 1116 al 1887 , Ann. Uff. Cent. Meteorol. Geodin. Ital., II (8), 1886/4, 183-205.

Volger, O. (1857): Untersuchungen über das Phänomen der Erdbeben in der Schweiz, Gotha, pp 367.

WorkING Group CPTI (1999): Catalogo Parametrico dei Terremoti Italiani (ING, GNDT, SGA, SSN, Bologna), pp. 92 (on line: http://emidius.mi.ingv.it/CPTI/home.html). 